\title{
SILVER-HAIRED BAT MIGRATION AT MATLOCK, MANITOBA
}

DOUG COLLISTER, 3426 Lane Cr. S.W., Calgary, AB. T3E 5X2

The Silver-haired Bat is found throughout Canada in summer, and is one of the most common bats in the prairie aspen parkland. ${ }^{5}$ The species tends to be solitary but may occur in small groups. At Delta Marsh in Manitoba single roosting bats were most common although groups of up to six were found. ${ }^{3}$ It inhabits woodlands or stands of trees in open country, preferably near ponds or streams, and roosts in trees, behind loose bark or in cavities. ${ }^{4}$ in 5 In Manitoba, the Silver-haired Bat is active throughout the night from just after sunset to just before sunrise. ${ }^{2}$ The species is migratory and moves south between mid-August and midSeptember. ${ }^{2}$ During migration it has been observed in flocks and has been associated with migrating birds. ${ }^{1}$ When migrating, Silver-haired
Bats may be found in diverse habitats and use a variety of roosts.

Silver-haired Bats were caught incidentally during a banding study of fall bird migration $8 \mathrm{~km}$ south of Winnipeg Beach at Matlock, Manitoba. Habitat at the study site includes scattered green ash (Fraxinus pennsylvanica) trees and a few white spruce (Picea glauca), with patches of red-osier dogwood (Cornus stolonifera) and cranberry (Viburnum opulus). Bats were captured in five 30 $\mathrm{mm}$ mist-nets placed in the same locations each year during the latter part of August. Table 1 summarizes the bats captured each year within the framework of days when capture was possible and not possible. No bat species other than silver-haired were detected. As my study was

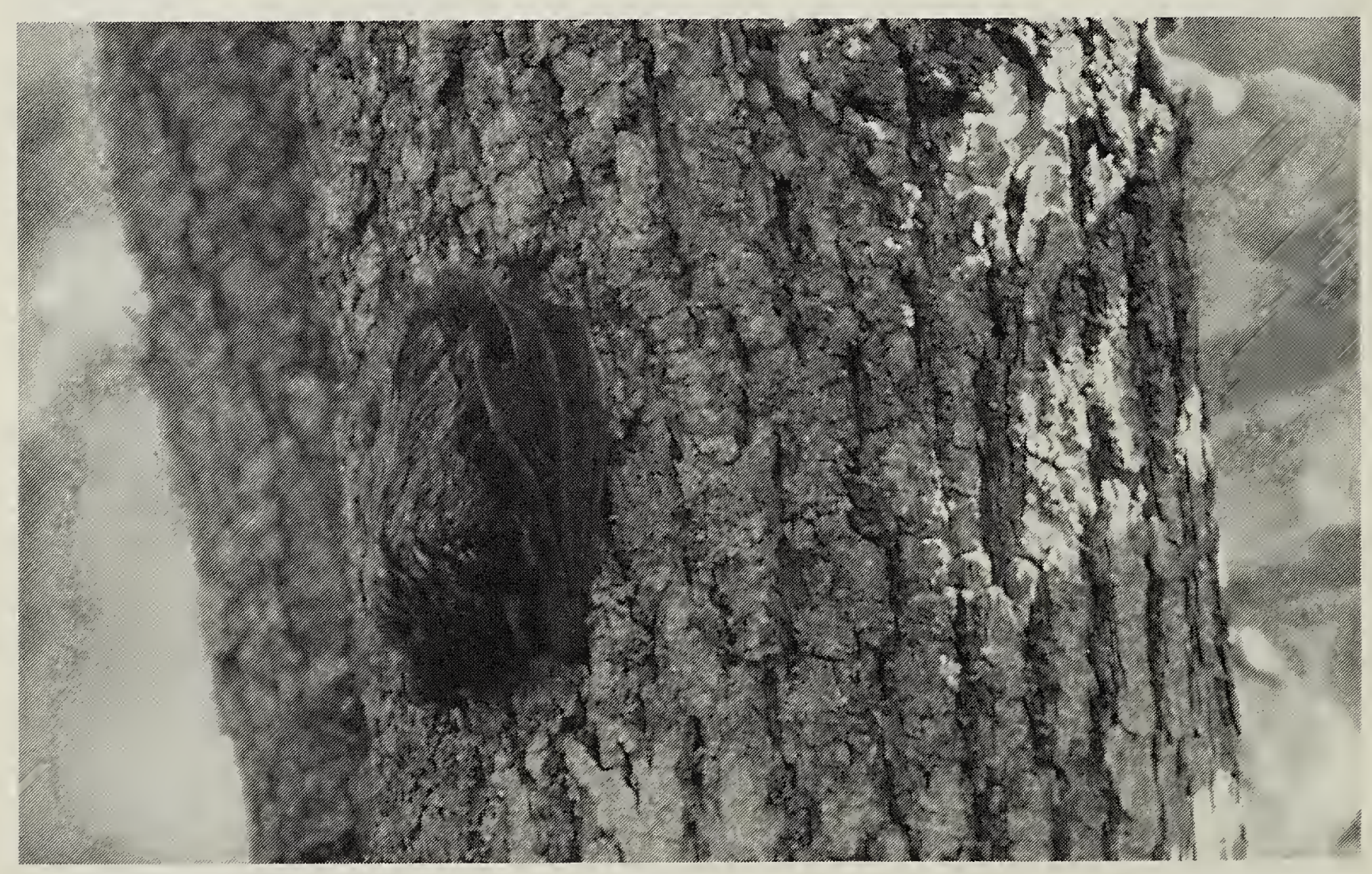


Table 1. SILVER-HAIRED BATS CAPTURED AT MATLOCK 1988-1992

\begin{tabular}{|c|c|c|c|c|c|c|}
\hline Date & 1988 & 1989 & 1990 & 1991 & 1992 & Total \\
\hline \multicolumn{7}{|l|}{11 August } \\
\hline \multicolumn{7}{|l|}{12 August } \\
\hline \multicolumn{7}{|l|}{13 August } \\
\hline 14 August & & & & & 1 & 1 \\
\hline 15 August & 3 & & 2. & & 3 & 6 \\
\hline \multicolumn{7}{|l|}{16 August } \\
\hline 17 August & 2 & & & & & 2 \\
\hline \multicolumn{7}{|l|}{18 August } \\
\hline \multicolumn{7}{|l|}{19 August } \\
\hline 20 August & 2 & $s_{2}$ & & & & 2 \\
\hline 21 August & 1 & & 1 & & & 2 \\
\hline \multicolumn{7}{|l|}{22 August } \\
\hline 23 August & & & 1 & & & 1 \\
\hline 24 August & & & 1 & & & 1 \\
\hline \multicolumn{7}{|l|}{25 August } \\
\hline \multicolumn{7}{|l|}{26 August } \\
\hline \multicolumn{7}{|l|}{27 August } \\
\hline 28 August & & 1 & & & & 1 \\
\hline 29 August & & 3 & 2 & & & 5 \\
\hline \multicolumn{7}{|l|}{30 August } \\
\hline \multicolumn{7}{|l|}{31 August } \\
\hline \multicolumn{7}{|l|}{01 Sept. } \\
\hline \multicolumn{7}{|l|}{02 Sept. } \\
\hline Total & 8 & 4 & 5 & & 4 & 21 \\
\hline
\end{tabular}

Note: Un-shaded cells represent days when nets were open and bats could have been captured, while shaded cells represent days when nets were furled and capture of bats was not possible.

focussed on bird migration, all bats netted were simply disentangled and set free. At least some individuals were males.

No bats were caught in the hours immediately after sunset. This suggests that most, if not all, were selecting a roost site when they became entangled in the mist-net. The majority were caught in nets placed adjacent to white spruce, although mature green ash with heavily furrowed bark were never more than a few metres away. Several individuals, when released, flew to green ash trees within view and crawled up to a suitable furrow in the bark where they remained through the day. This is consistent with the finding at Delta Marsh that older trees with furrowed bark are selected for roosting. ${ }^{3}$ At Delta Marsh 176 out of 177 roosting bats were found below $3 \mathrm{~m}$ suggesting that bats seeking roost sites would be susceptible to capture in $2 \mathrm{~m}$ high mist-nets. ${ }^{3}$

No correlation between bat captures and the peak of birds banded each year was found. However it seems likely that the Silver-haired Bats were captured while migrating. At Delta Silver-haired Bat fall migration peaked in early September. ${ }^{2}$ Matlock lies on the southwestern shore of Lake Winnipeg and experiences a fall concentration of migrating passerines reluctant to cross the lake. Migrating Silver-haired Bats 
may also be reluctant to risk crossing. Alternatively, it is possible that the captured bats represent a resident population. However, in that case a more even distribution of captures over the banding periods, or captures concentrated at the commencement of banding, might have been expected.

Acknowledgements This note was improved through a critical review by Jack Dubois.

1. BANFIELD, A.W.F. 1974. The mammals of Canada. University of Toronto Press, Toronto. 438 pp.
2. BARCLAY, R.M.R. 1984. Observations on the migration, ecology and behavior of bats at Delta Marsh, Manitoba. Can. Field-Nat. 98:331-36.

3. BARCLAY, R.M.R., P.A. FAURE and D.R. FARR. 1988. Roosting behavior and roost selection by migrating Silverhaired Bats (Lasionycteris noctivagans). J. Mamm. 69:821-25.

4. KUNZ, T.H. 1982. Lasionycteris noctivagans. Mammal. Species 172: 1-5.

5. VAN ZYLL DE JONG, G.G. 1985. Handbook of Canadian mammals. Vol. 2, Bats. National Museum of Canada, Ottawa. 212 pp.

\section{ERRATA}

\section{PIKE LAKE BUTTERFLY CENSUS 1986-1992}

\section{KEN PIVNICK, 209 - 7th Street East, Saskatoon, SK. S7H OW9}

In $1994^{2}$ I reported 34 and $66 \mathrm{Al}$ falfa Butterflies (now called the Orange Sulphur) censused in 1986 and 1988 respectively, but no Common Sulphurs (now called the Clouded Sulphur). The primary source ${ }^{i}$ used for identification in those census years treated these two butterflies as two subspecies of the Alfalfa Butterfly. When I was questioned about this recently I examined a few pinned specimens I collected during those censuses and found both species had been present. Hence, for those two years, the Alfalfa Butterflies reported are actually some combination of the two species.

1. HOOPER, R.R. 1973. Butterflies of Saskatchewan: a field guide. Royal Saskatchewan Museum, Regina. 216 pp.

2. PIVNICK, K. 1994. Pike Lake butterfly census 1986-1992. Blue Jay 52:1-3. 